\title{
External Lip
}

National Cancer Institute

\section{Source}

National Cancer Institute. External Lip. NCI Thesaurus. Code C12223.

One of two visible fleshy folds that surround the orifice of the mouth. 